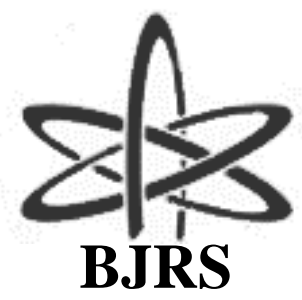
BRAZILIAN JOURNAL
OF
RADIATION SCIENCES
09-01 (2021) 01-20

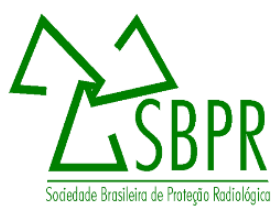

\title{
Variation in radon concentration in soil gases to detect the NAPL presence
}

\author{
Bonfim $^{a}$ S. A., Rocha ${ }^{b}$ Z., Jonusan ${ }^{a}$ R. A. S., Franklin ${ }^{c}$ M. R., Ferreira ${ }^{c}$ P. R. R., \\ Santos $^{\mathrm{a}}$ T. O., Oliveira ${ }^{\mathrm{a}}$ A. H. \\ ${ }^{a}$ Universidade Federal de Minas Gerais \\ UFMG, Av. Presidente Antônio Carlos, 6627 - Belo Horizonte-MG-Brasil. \\ sarah_andresa@hotmail.com \\ arno@nuclear.ufmg.br \\ ${ }^{b}$ Centro de Desenvolvimento da Tecnologia Nuclear \\ CDTN, Av. Antônio Carlos, 6627 Campus UFMG - Belo Horizonte - MG-Brasil. \\ zildeter7@gmail.com \\ ${ }^{c}$ Instituto de Radioproteção e Dosimetria \\ IRD, Av. Salvador Allende s/n - Barra da Tijuca - Rio de Janeiro - RJ - Brasil.
}

\begin{abstract}
Non-Aqueous Phase Liquids (NAPLs) compounds are complex mixtures of organic liquids derived from petroleum or other industrial activities. Contamination of soils and groundwater by NAPLs can generate health and economic problems by compromising water resources, restrict soil use, and cause damage to the public and private patrimony and the environment. In the last decades, there has been an increase in areas contaminated by different types of NAPLs, a cause of great concern worldwide, mainly due to the difficulty of locating and quantifying contamination. These issues are majors obstacles that prevent the cleaning of soils and groundwater in affected locations. This work aims to use the concentrations of the Radon gas in the soil to identify areas contaminated by NAPL. The high affinity of the Radon for NAPLs causes a Radon deficit in soil gas in relation to the background observed in the studied region. After understanding the Radon affinity between soil gas, groundwater and NAPLs, a known contaminated area with diesel oil from a gas station spill was chosen to validate the methodology. Measurements of the Radon concentration were carried out with the AlphaGUARD ${ }^{\circledR}$ Radon monitor. These measurements confirmed the deficit in Radon concentration, which demonstrated the
\end{abstract}


ability of this radionuclide to be used as a tracer for NAPL contamination, contributing to plans for remediation and control of pollution, as well as studies of oil wells on-shore. 


\section{INTRODUCTION}

Non-Aqueous Phase Liquids (NAPLs) are complex mixtures of organic liquids, which can be classified for their density. They may be less dense than water, the LNAPLs (light non-aqueous phase liquids) commonly associated with the production, refining and distribution of petroleum derivatives such as gasoline, diesel and benzene; or denser than water, DNAPLs (dense nonaqueous phase liquids) associated with various industrial activities, such as organic solvents as chlorinated, perchloroethylene and trichloroethylene [1]. Thus, many industrial processes use petroleum products in their production, which allows the increase of waste and effluent contaminated with NAPL compounds. In addition, the refining and storage of petroleum have become a concern when contamination of soils and groundwater is considered, since it is a potentially polluting activity.

The increasing and intense utilization of NAPLs in the production, storage and handling of fuels, besides the use in industrial processes, causes losses in the quality of soils and groundwater. The residual or combined NAPL contamination provides a source of long-term contamination due to the slow dissolution rate of the compounds into the water. Nowadays, an increase in NAPL contamination is observed, which is a worldwide concern. The difficulty of locating and quantifying the contamination, accurately and economically is a major obstacle that prevents the cleaning of soils and aquifers in affected local [2].

As in the rest of the world, contamination of soils and aquifers by petroleum derivatives on a large-scale can also be observed in Brazil. According to the National Petroleum Agency (Agência Nacional do Petróleo - ANP), Brazil has increased the number of gas stations and currently has more than 41,000 oil derivative resellers, being the seventh country in the ranking of the world's largest oil consumers [3]. In this scenario, there is also an increase in the number of contaminated areas resulting from gas stations, including the fuel retail business and resellers of gasoline, alcohol and diesel. A report for the year 2016 prepared by the State Environmental Foundation of Minas Gerais (Fundação Estadual de Meio Ambiente de Minas Gerais - FEAM) shows 642 contamination sites in Minas Gerais, and most of these environments, 74\%, correspond to fuel stations [4].

The significant contamination of soils and, consequently, groundwater with petroleum and its derivatives, NAPL, demonstrates the need to know and recover the contaminated areas in order to 
allow their future use. In the search for a correct risk assessment and remediation plan of sites contaminated by NAPL, it is necessary to know the precise location as well as the quantitative estimate of the residual NAPL source in the studied environment. As NAPL contamination does not follow a pattern in all localities, it spreads unevenly and erratically, conventional means such as soil extraction with laboratory analysis of samples are limited ways of knowing the contamination in order to ensure its correct remediation. Thus, it is important to search for innovative and adequate techniques for the evaluation of subsurface contamination by NAPLs, such as using the radiation emitted by Radon $\left({ }^{222} \mathrm{Rn}\right)$ in soil gases [5].

The ${ }^{222} \mathrm{Rn}$ has a strong affinity for organic substances. Laboratory and field experiments have shown that in the presence of NAPLs, the ${ }^{222} \mathrm{Rn}$ concentration in soils and groundwater is reduced due to its preferential dissolution in the NAPL phase. Assuming that the concentration of Radio $\left({ }^{226} \mathrm{Ra}\right)$ and the pore size distribution is homogeneous in the soil matrix, the ${ }^{222} \mathrm{Rn}$ concentration in NAPLs contaminated areas would be significantly lower than in non-contaminated areas. This characteristic allows a delimitation of the contamination, as well as its qualitative and quantitative analysis [6]. The purpose of this paper was to demonstrate the potential use of ${ }^{222} \mathrm{Rn}$ in the analysis of the contamination by NAPLs in gas stations, by means laboratory and field experiments for the knowledge of the radon partition coefficient between water, air and some types of NAPL, as well as the measurement of the concentration of ${ }^{222} \mathrm{Rn}$ in a known contaminated area.

\section{THEORETICAL BACKGROUND}

\subsection{Radon partition coefficient}

The partition coefficient, or distribution, is a quantity that informs the tendency of a solute to be distributed between two non-miscible phases, indicating the preferential tendency of a solute to dissolve in one of the phases. The magnitude is defined as the ratio between solute concentrations in the phases [7]. Considering the ${ }^{222} \mathrm{Rn}$ as the solute and the phases of NAPL and water as the phases through which it will distribute, the equation of the distribution coefficient is: 


$$
K_{N A P L / W}=\frac{C_{N A P L}}{C_{w}}
$$

Where $\mathrm{K}_{\mathrm{NAPL} / \mathrm{w}}$ is the ${ }^{222} \mathrm{Rn}$ partition coefficient between NAPL and water phases, $\mathrm{C}_{\mathrm{NAPL}}$ is the concentration of ${ }^{222} \mathrm{Rn}$ in the NAPL phase and $\mathrm{C}_{\mathrm{w}}$ is the concentration of ${ }^{222} \mathrm{Rn}$ in the water phase [8].

It is known that the concentration of ${ }^{222} \mathrm{Rn}$ in the part of the aquifer contaminated with NAPL is clearly lower than in uncontaminated water [6]. This concentration decreases as a function of the residual saturation of NAPL in the pore space $\left(S_{\text {NAPL }}\right)$; of the ${ }^{222} R n$ partition coefficient between the phases $\left(\mathrm{K}_{\mathrm{NAPL} / \mathrm{W}}\right)$ and; of factors common to the concentration of ${ }^{222} \mathrm{Rn}$ in an aquifer such as: ${ }^{222} \mathrm{Rn}$ emanation coefficient $(\varepsilon)$, porosity $(\mathrm{n}),{ }^{226} \mathrm{Ra}$ activity in the matrix $\left(\mathrm{A}_{\mathrm{Ra}}\right)$ and apparent density of the matrix $\left(\rho_{d}\right)$. Therefore, it can be seen how the partition coefficient can contribute to the determination of the contamination of an aquifer and, thus, the concentration of ${ }^{222} \mathrm{Rn}$ in a water contaminated by NAPL is given by [8]:

$$
\mathrm{C}_{W}=\frac{\varepsilon \cdot \mathrm{A}_{\mathrm{Ra}} \cdot \rho_{\mathrm{d}}}{\mathrm{n} \cdot\left(1-\mathrm{S}_{\mathrm{NAPL}}+\mathrm{K}_{\mathrm{NAPL} / \mathrm{W}} \cdot \mathrm{S}_{\mathrm{NAPL}}\right)}
$$

\subsection{Hildebrand Parameter}

Although inert, the ${ }^{222} \mathrm{Rn}$ gas presents good solubility in NAPLs, being about 40 times more soluble in NAPL than in water, when under the same temperature conditions. This solubility of ${ }^{222} \mathrm{Rn}$ in NAPL can be explained quantitatively using the Hildebrand Parameter, which is defined as the square root of cohesive energy per unit volume [6]:

$$
\delta=c^{\frac{1}{2}}\left[P a^{\frac{1}{2}}\right]
$$

Where $\mathrm{c}$ is the density of cohesive energy, which is given by: 


$$
c=\frac{\Delta_{l} \cdot U_{g}}{V},[P a]
$$

Where $\left(\Delta_{1} \cdot U_{g}\right)$ is the molar vaporization energy, ie, the energy required to vaporize one mole of a substance, and $\mathrm{V}$ is the volume of the substance. Using molar enthalpy of vaporization, knowing that $\mathrm{R}$ is the general gas constant and $\mathrm{T}$ is the temperature, the calculation of the Hildebrand Parameter is [6]:

$$
\delta=\sqrt{\frac{\Delta_{l} H_{g}-R T}{V}}
$$

The higher solubility of ${ }^{222} \mathrm{Rn}$ in NAPL than in water can be explained by the Hildebrand parameter, however, it is important to emphasize that this parameter is a property of the liquid state of matter, so when it comes to gases they should be treated as hypothetically liquid solutes at atmospheric pressure. A substance with a high Hildebrand parameter requires greater dispersive energy when mixed with a low-parameter substance, which results in immiscibility, but two substances of similar Hildebrand parameters have sufficient dispersive energy to solubilize [6].

The Hildebrand parameter is related to the ${ }^{222} \mathrm{Rn}$ partition coefficient between NAPL and water which, as already mentioned, indicates the tendency of a solute to solubilize in one or another phase. This relationship can be seen in Figure 1, where it is observed that substances with similar Hildebrand parameters tend to be miscible.

The substances with higher ${ }^{222} \mathrm{Rn}$ partition coefficient between them and air, present the Hildebrand parameter close to $18 \mathrm{MPa}^{1 / 2}$, which is the parameter already calculated for the ${ }^{222} \mathrm{Rn}$. Such Radon solubility in water is low due to its high Hildebrand parameter value. $\left(\delta=47,9 \mathrm{MPa}^{1 / 2}\right)[9]$. 


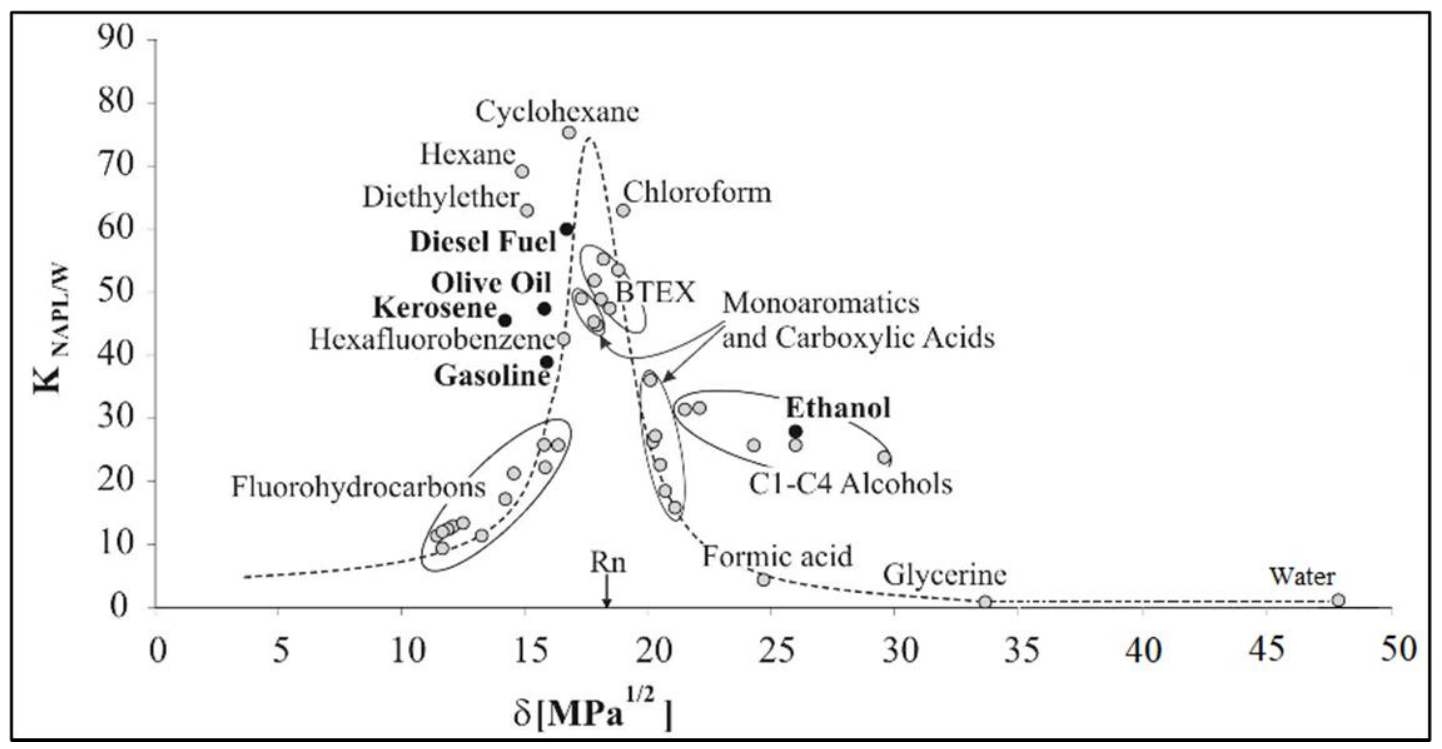

Figure 1: Hildebrand parameter for some NAPLs, water and ${ }^{222} R n\left(\delta=18 \mathrm{MPa}^{1 / 2}\right.$ - indicated by the arrow) at $20^{\circ} \mathrm{C}$ versus the partition coefficient of radon $K_{\text {NAPLAir }}$ and $K_{\text {W/air }}$ (for water).

Source: SCHUBERT, 2001

\section{STUDY AREA}

\subsection{General aspects}

For the development of this study, it was necessary to identify an area that it was known contaminated with some type of NAPL. Thus, with the contribution of the Minas Gerais State Secretariat for the Environment, it was possible to identify a gas station located in the western region of Belo Horizonte (Minas Gerais - BR) where there was a contamination by diesel oil. This contaminated area had already been studied and the contamination source (fuel tank) had already been removed, but the contamination plume was still being monitored. Since contamination and the probable size plume were already known, this gas station was chosen, making it possible to validate the method studied here.

The western region of Belo Horizonte has important urban references such as exhibition parks, schools, universities, subway stations and several gas stations. It is a region with rugged topography, in general, presenting a variable slope of 20 to 50\% [10]. The predominant soil in the studied 
region, according to the Brazilian Agricultural Research Corporation (Empresa Brasileira de Pesquisa Agropecuária - Embrapa) data, is the red-yellow ultisol [11]. This type of soil is distributed throughout the State of Minas Gerais and is characterized by being shallow to deep, well to moderately drained, with varying gravel contents and block structure [12]. It occurs along the Velhas river, in the central-north portion covering much of the territory of the Metropolitan Region of Belo Horizonte $(\mathrm{RMBH})$. It is predominantly kaolinitic, commonly well drained and clayey in texture [13]. In relation to lithology of the studied area, there is a predominance of metamorphic rock associated with shale [14]. Figure 2 shows the pedological and lithological map of the area.

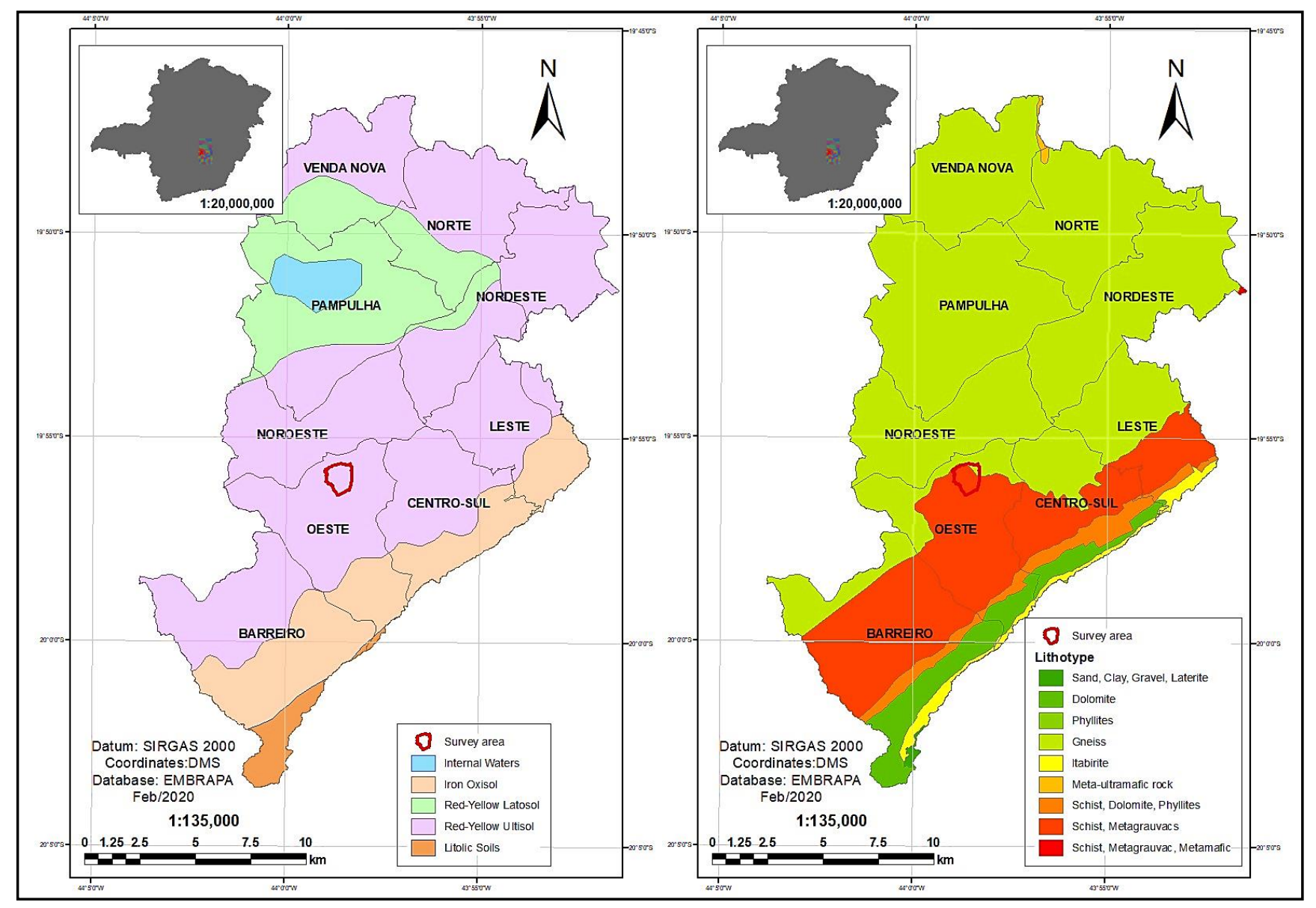

Figure 2: The map on the left represents the pedology of the region studied and the one on the right represents the lithology.

Source: Data in GEOINFO, 2004 


\subsection{Radon distribution}

The ${ }^{222} \mathrm{Rn}$ comes from the radioactive decay of ${ }^{226} \mathrm{Ra}$. This atom in turn can be found in all mineral material, in greater or lesser concentration. Thus, ${ }^{222} \mathrm{Rn}$ will also be found in all terrains, and spatial distribution of its activity concentration will vary according to the lithological, pedological and geochemical characteristics of the area. Each region then presents a ${ }^{222} \mathrm{Rn}$ concentration profile that, when it varies due to factors not related to the mentioned characteristics, indicates processes or conditions outside the natural standard [15].

The distribution of the concentration of ${ }^{222} \mathrm{Rn}$ in soil gases in Metropolitan Region of Belo Horizonte (RMBH) was measured by LARA et al. 2011, which showed that approximately $70 \%$ of the soils, in the different lithologies and pedological profiles, presented concentrations of ${ }^{222} \mathrm{Rn}$ in the range of 10.0 to $50.0 \mathrm{kBq} \cdot \mathrm{m}^{-3}$ [16]. This spatial distribution in concentration of ${ }^{222} \mathrm{Rn}$ makes RMBH a good place to study the relationship between ${ }^{222} \mathrm{Rn}$ and its affinity with different types of NAPLs, since for regions with low concentrations of ${ }^{222} \mathrm{Rn}$, i.e., regions where radon concentrations are naturally less than $5 \mathrm{kBq} \cdot \mathrm{m}^{-3}$, this methodology does not apply. In the study area, located in the western region of Belo Horizonte, it can be seen that the ${ }^{222} \mathrm{Rn}$ concentration ranges from $24.0 \pm 2.2$ $\mathrm{kBq} \cdot \mathrm{m}^{-3}$ to $46.5 \pm 9.9 \mathrm{kBq} \cdot \mathrm{m}^{-3}[13]$.

\section{MATERIALS AND METHODS}

For the experiments, the AlphaGUARD ${ }^{\circledR}$ portable radon monitor, model PQ 2000 PRO, was used, which was set to operate in continuous flow mode with a one-minute interval between measurements. This equipment measures the alpha particles emitted by $\mathrm{Rn}$ isotopes of the air through the total charge produced by the ionization of a gaseous medium [17]. The data obtained in the measurements were collected and processed by DataExpert software and by Excel.

\subsection{Partition Coefficient}

The measurement of the partition coefficient of Rn between water and diesel was done through a closed system circuit, as shown in Figure 3. In the circuit was placed a gas pump (maintained at a constant flow rate of $0.5 \mathrm{~L} / \mathrm{min}$ ), an AlphaGUARD ${ }^{\circledR}$ monitor, a $600 \mathrm{~mL}$ vessel for water, a $150 \mathrm{~mL}$ 
safety vessel and plastic hoses, which ensured the minimal loss of Rn from the system by diffusion. $450 \mathrm{~mL}$ of well water was placed in the water vessel and the concentration of $\mathrm{Rn}$ in the water was measured up to the stability of the system. After the Rn concentration in the system reached stabilization, a $300 \mathrm{~mL}$ container with $200 \mathrm{~mL}$ of diesel was added to the circuit (between the water and the safety vessel), reconnecting the gas pump until further stabilization of the $\mathrm{Rn}$ concentration.

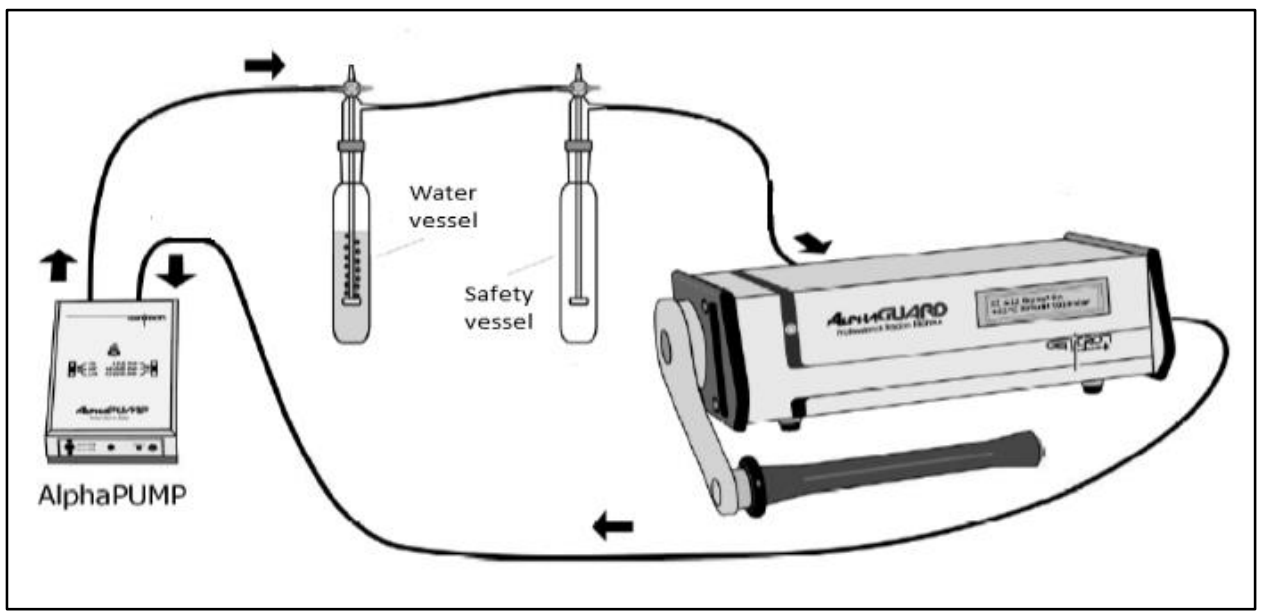

Figure 3: Closed system assembled for analysis of Radon concentration. Source: Manual for AlphaGUARD PQ2000 PRO (Modified)

The calculation of the $\mathrm{Rn}$ partition coefficient for Diesel and water depends on the partition coefficient between water and air $\left(\mathrm{K}_{\mathrm{w} / \mathrm{air}}\right)$, which is a function of temperature. The temperature considered was $20^{\circ} \mathrm{C}$, which was the temperature of the system during the measurements; the $\mathrm{K}_{\mathrm{w} / \mathrm{air}}$ used in the calculations was obtained using:

$$
K_{w / \text { air }}=0,105+0,405 e^{\left.-0,0502 \cdot T{ }^{\circ} \mathrm{C}\right]}
$$

The result obtained was 0.25 . The mean values of the concentrations $\left(\mathrm{C}^{*}\right.$ air $)$ in the first phase of the experiment (water balance) were converted into an inventory (I) for the closed system used by Schubert et al. [8] by the following equation:

$$
I=C_{\text {air }}^{*} \cdot\left(V_{\text {air }}^{*}+K_{w / a i r} \cdot V_{w}\right)
$$


Where $\mathrm{V}^{*}$ air is the volume of air in the system, which at that time was $1010 \mathrm{~mL}$, and $\mathrm{V}_{\mathrm{w}}$ the volume of water, which in this case was $450 \mathrm{~mL}$.

For the second phase of the experiment (after addition of NAPL), the mean value of Rn concentration in the air of the system $\left(\mathrm{C}^{* *}\right.$ air $)$ was used to determine the $\mathrm{Rn}$ partition coefficient between diesel and water $\left(\mathrm{K}_{\mathrm{NAPL} / \mathrm{w}}\right)$ using the inventory previously calculated, as described in the equation below:

$$
K_{N A P L / w}=\frac{I}{V_{N A P L} K_{w / a i r} C_{a i r}^{* *}}-\frac{V_{\text {air }}^{* *}}{V_{N A P L} K_{w / a i r}}-\frac{V_{w}}{V_{N A P L}}
$$

Where $\mathrm{V}_{\mathrm{NAPL}}$ is the volume of diesel in the system, which was $200 \mathrm{~mL}, \mathrm{~V}^{* *}$ air is the air volume at this stage of the experiment, which was $1144 \mathrm{~mL}$. For the calculation of the partition coefficient between the diesel and the air $\left(\mathrm{K}_{\mathrm{NAPL} / \text { air }}\right)$ the following equation was used:

$$
K_{N A P L / a i r}=K_{N A P L / w} \cdot K_{w / a i r}
$$

\subsection{Measurement of Radon concentration in the gases of soil contaminated by diesel}

As previously mentioned, with the contribution of the Belo Horizonte City Hall (PMBH), it was possible to identify a gas station contaminated by diesel oil located in the western region of Belo Horizonte. Previously, a study of the contamination plume was carried out in this area, which was presented to us to choose suitable locations for measuring the Rn concentration in soil gases. Twenty-two points were selected considering the need for the functioning of the gas station, the paving of the streets and the floor of the place, as well as the plume itself.

For the measurement of $\mathrm{Rn}$, a metal probe was used, which was inserted into the ground with the aid of a hammer to a depth of 0.7 meters. A previous study carried out by Schubert and Schulz showed that, at this depth, there is no significant atmospheric interference [18]. A capillary tube was used to remove the probe seal and to allow soil gases to be sucked by an air pump (AlphaPUMP ${ }^{\circledR}$ $1{\mathrm{~L} . \mathrm{min}^{-1}}^{\text {) and transported to the monitor AlphaGUARD }}{ }^{\circledR}$ (Figure 4). The soil gases were forced to flow continuously through the capillary tube and, thus, go into the detector, where the $\mathrm{Rn}$ 
concentrations measurements are made. The pump remained on until the activity concentration of ${ }^{222} \mathrm{Rn}+$ Toronium $\left({ }^{220} \mathrm{Rn}\right)$ recorded gained stability. After that time the pump was turned off, however, the count remained until the complete disappearance of the ${ }^{220} \mathrm{Rn}$ atoms due to its decay. When a new equilibrium in concentration measurements was observed, only ${ }^{222} \mathrm{Rn}$ was being counted.

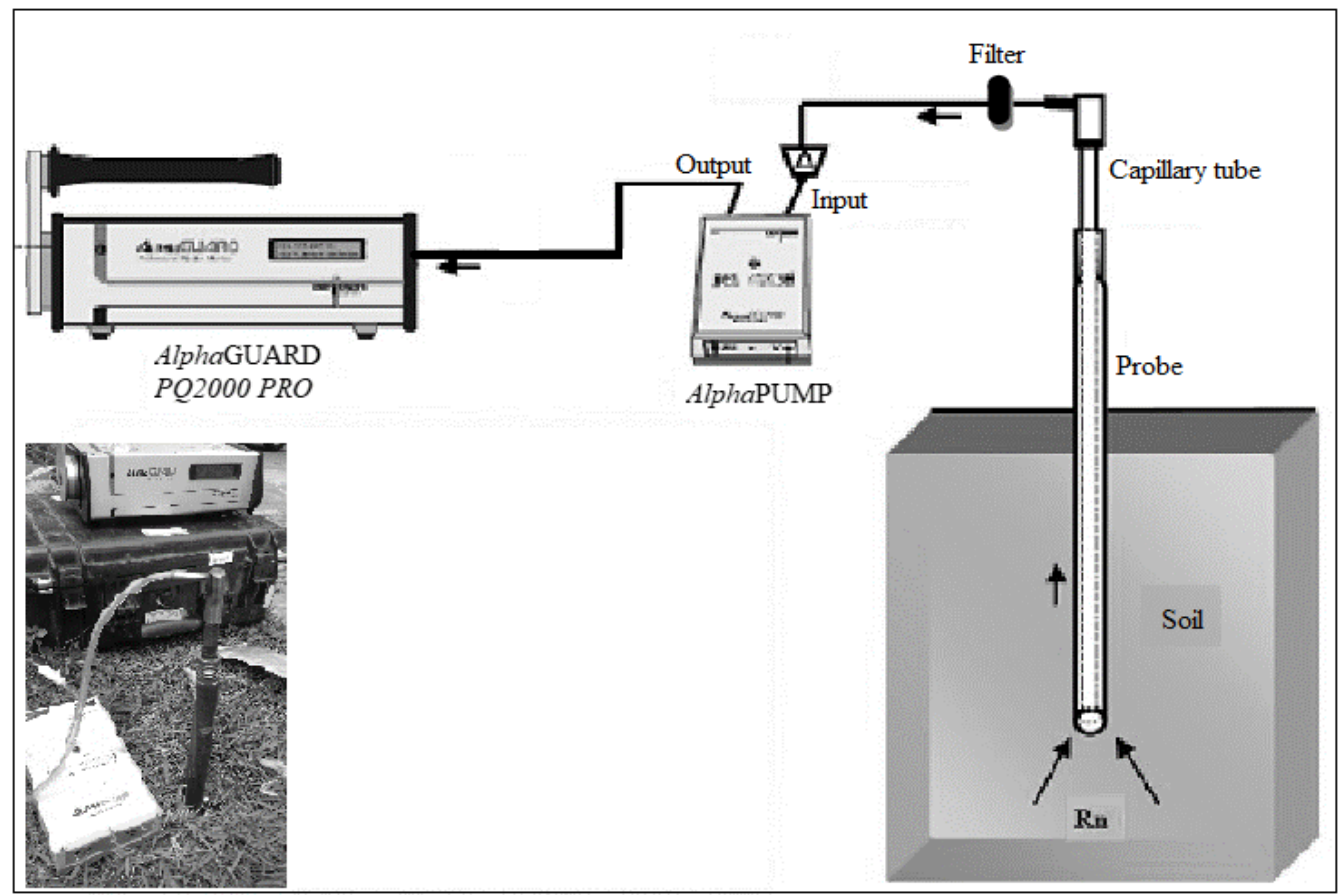

Figure 4: Assembly for Radon measurement in soil gases.

Source: LARA, 2013 (Modified)

\section{RESULTS AND DISCUSSION}

\subsection{Partition Coefficient}

Four measurements were carried out, and results were analyzed as previously described, the coefficients of each sample of diesel analyzed were obtained by calculating the mean and the standard deviation. The following partition coefficient values were obtained: 
Table 1: Radon partition coefficient results.

\begin{tabular}{|c|c|c|c|}
\hline & \multirow{2}{*}{\multicolumn{2}{|c|}{ Radon Partition Coefficient }} & \multirow[b]{2}{*}{$\mathbf{K}_{\text {DIESEL/air }}$} \\
\hline & & & \\
\hline Diesel & 74.56 & 71.49 & $18.66 \pm 0.60$ \\
\hline
\end{tabular}

Although inert, the $\mathrm{Rn}$ gas presents good solubility in diesel, as shown in the partition coefficient calculation, being about 300 times more soluble in NAPL than in water, when under the same temperature conditions. This solubility of Rn in NAPL can be explained quantitatively using the Hildebrand parameter. Figure 5 shows the partition coefficient of diesel and some other organic compounds (tabulated) related to the Hildebrand parameter. It is observed that diesel has a parameter very close to Rn (indicated by the arrow), which justifies its good solubility in this NAPL and the partition coefficient value found. Such Rn solubility is not verified in water due to its high Hildebrand parameter $\left(\delta=47.9 \mathrm{MPa}^{1 / 2}\right)[9]$.

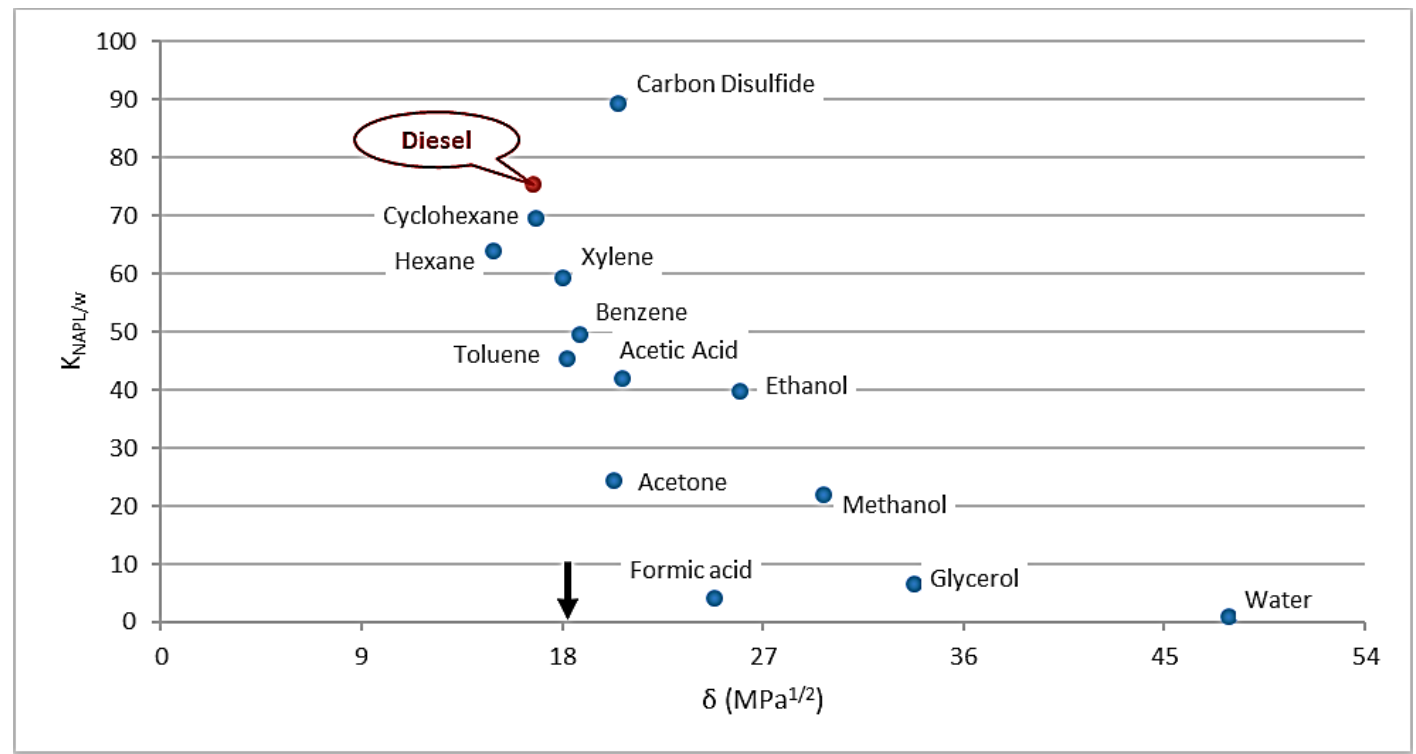

Figure 5: Partition Coefficient per Hildebrand Parameter. 


\subsection{Radon in contaminated soil}

After the analysis of the contamination plume's map made available by the owner of the gas station studied, the possible measurement sites were chosen, considering the limitations given by the need for gas station operation, besides the difficulties of access to the ground due to the floor and paving of the access roads. Thus 22 points were chosen (Figure 6) and measured. The results of measurements of the radon concentration in the soil gases can be visualized in Table 2.

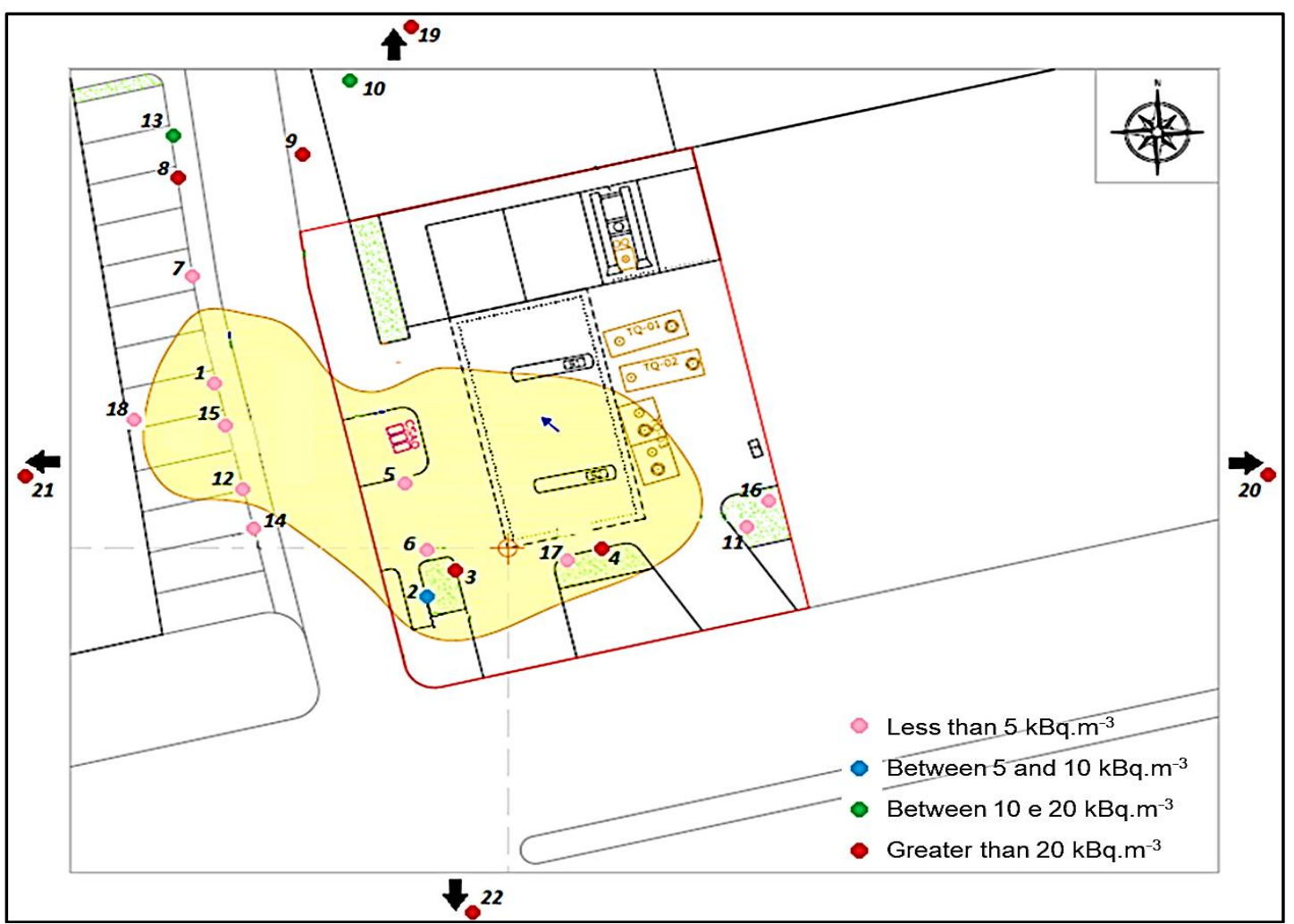

Figure 6: Measurement points of the Radon concentration in the soil gases. In yellow area, the known contamination plume.

The result of the measurements in an area known to be contaminated shows that some points chosen within the plume of contamination presented are above the expected values considering diesel contamination (points 3 and 4). Similarly, some measurements taken outside the plume showed values below those expected for the region under study, which are values above $26 \mathrm{kBq} \cdot \mathrm{m}^{-3}$ [13], as the measures in points $7,11,14,16,18$. 
Several factors may justify the divergent concentrations expected at these points. Firstly, the gas station owner informed that repairs were carried out to remove the damaged fuel tank (NAPL source), and the soil was probably turned over, allowing getting uncontaminated samples or hiding the contamination. For points 3 and 4, we still have the fact that they may be at the limit of the contamination plume, so it may have a different contour from that presented by the previous study that defined the contamination.

Table 2: Result of the concentrations of Radon in the soil gases of the selected points.

\begin{tabular}{|c|c|c|c|}
\hline Measure & $\begin{array}{l}\text { Conc. de }{ }^{222} \mathrm{Rn} \\
\left(\mathrm{kBq} \cdot \mathrm{m}^{-3}\right)\end{array}$ & Measure & $\begin{array}{l}\text { Conc. de }{ }^{222} R n \\
\left(k B q . m^{-3}\right)\end{array}$ \\
\hline 1 & $0,62 \pm 0,07$ & 12 & $0,36 \pm 2,1$ \\
\hline 2 & $5,0 \pm 1,5$ & 13 & $16,3 \pm 3,4$ \\
\hline 3 & $27,1 \pm 3,6$ & 14 & $0,20 \pm 1,4$ \\
\hline 4 & $36,4 \pm 1,9$ & 15 & $2,6 \pm 1,2$ \\
\hline 5 & $0,97 \pm 0,7$ & 16 & $0,5 \pm 0,1$ \\
\hline 6 & $1,4 \pm 0,7$ & 17 & $4,5 \pm 2,9$ \\
\hline 7 & $2,8 \pm 1,7$ & 18 & $2,5 \pm 1,8$ \\
\hline 8 & $21,8 \pm 3,5$ & 19 & $29,3 \pm 2,5$ \\
\hline 9 & $20,8 \pm 2,6$ & 20 & $40,2 \pm 4,1$ \\
\hline 10 & $11,02 \pm 3,5$ & 21 & $38,5 \pm 2,9$ \\
\hline 11 & $0,5 \pm 0,04$ & 22 & $32,3 \pm 3,5$ \\
\hline
\end{tabular}

For the other points cited in nonconformity, the low concentration of ${ }^{222} \mathrm{Rn}$ can be explained by the direction of the underground flow of the contamination plume, which may still be expanding or migrating. After the study for the determination of the map of the plume presented, it may have changed and may be relatively larger, which suggests that it should still be monitored and remediation measures must be taken at the site. As the NAPL source has already been withdrawn, it is expected that it will stop expanding or migrate with proper remediation of the plume area, until the environmental agencies solve the problem.

The Figure 7 graphically represents the drop in radon concentration at diesel contaminated sites. It was constructed using the data obtained in this work and it is possible to see how the concentration of radon in the contamination zone is much smaller than the concentration observed around and far from the plume, proving the effectiveness of the technique used. 


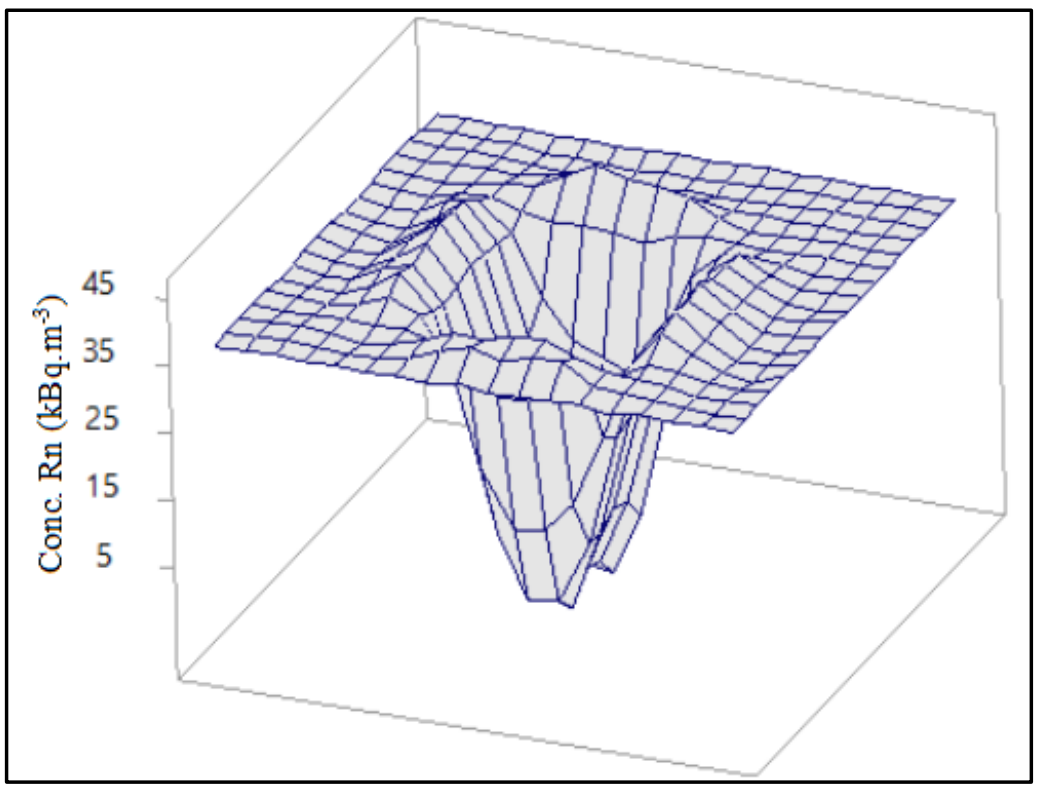

Figure 7: Graph showing the strong drop in the distribution of Radon concentration in the plume of contamination.

\section{CONCLUSION}

The experimentally obtained partition coefficients allowed to demonstrate the great affinity of the radon in solubilizing in mixtures like the NAPLs, which can be observed by the high values presented when compared with $\mathrm{K}_{\mathrm{NAPL} / \mathrm{air}}$ and $\mathrm{K}_{\mathrm{w} / \mathrm{air}}$. Furthermore, it is observed that the affinity shown by the partition is also proved by the Hildebrand solubility parameter, NAPLs with high partition coefficient present this parameter close to the $\mathrm{Rn}\left(\delta^{2}=18 \mathrm{Mpa}^{1 / 2}\right)$, indicating good solubility.

Besides the knowledge of the Hildebrand parameter, the calculation of the radon partition coefficient between water and diesel reinforces the viability of the study proposed in this paper, since it proved the preference of $\mathrm{Rn}$ for this organic liquid. The $\mathrm{K}_{\mathrm{DIESEL} / \mathrm{w}}(74.63 \pm 2.41)$ found is a very high value when compared to $\mathrm{K}_{\mathrm{DIESEL} / \mathrm{air}}(18.66 \pm 0.60)$ and $\mathrm{K}_{\mathrm{w} / \mathrm{air}}(0.25)$ under the same temperature conditions $\left(20^{\circ} \mathrm{C}\right)$. In addition, the value of $\mathrm{K}_{\mathrm{DIESEL} / \mathrm{w}}$ found matches the revised theory, in a similar experiment Schubert et al found a $\mathrm{K}_{\mathrm{DIESEL} / \mathrm{w}}$ of $60.0 \pm 1.3$ [19], that is, a value close to that obtained. The variation observed in the values can be explained by the great difference in the composition of 
the NAPLs presented for each region, and for this reason it can be considered that the values obtained were satisfactory.

As the identification of affinity of Rn for NAPL is significant in relation to water and air, the measurement of $\mathrm{Rn}$ in soil contaminated with diesel allowed the validation of a non-invasive method for the determination of contamination plumes at gas stations or in other contaminated areas. It was observed that outside the contamination plume, the Rn concentration in the soil gases is significantly higher than the concentration in the plume region, with values obtained outside the plume being above $20.0 \mathrm{kBq} \cdot \mathrm{m}^{-3}$, as expected for the western region of Belo Horizonte according to studies by LARA, 2013 [13]. However, there is a sharp drop in these values in the plume region, in this case, the measured concentration varied between $0.2 \pm 1.4 \mathrm{kBq} \cdot \mathrm{m}^{-3}$ and $5.0 \pm 1.5 \mathrm{kBq} \cdot \mathrm{m}^{-3}$, according to the theory studied and showing the efficiency of the method.

The results obtained in the experiments presented in this paper allow further studies on NAPL, soils and groundwater contamination, as well as studies of on-shore oil prospecting. Data presented by the Brazilian Institute of Petroleum, Gas and Biofuels (Instituto Brasileiro de Petróleo, Gás e Biodiesel - IBP) show the importance of investing in the exploration of new frontiers and revitalizing the production of mature on-shore basins [20]. The use of innovative techniques, noninvasive and with low cost of prospecting is an issue that deserves encouragement and research from the Brazilian industry. 


\section{ACKNOWLEDGMENT}

To the professors and colleagues of the Department of Nuclear Engineering of the UFMG (Departamento de Engenharia Nuclear - DEN-UFMG), the Institute of Radiation Protection and Dosimetry (Instituto de Radioproteção e Dosimetria - IRD) and the Foundation for Research Support of Minas Gerais (Fundação de Amparo à Pesquisa de Minas Gerais - FAPEMIG).

\section{REFERENCES}

[1] MATHEUS. C. et al. "Radônio como indicador de contaminação ambiental por hidrocarbonetos em fase livre". Instituto de Pesquisas Energéticas e Nucleares - IPEN. Pós-Graduação em Ciências e Tecnologia Nuclear da Universidade de São Paulo - USP.2016.

[2] SEMPRINI, Lewis; ISTOK, Jonathan. "Radon-222 as a Natural Tracer for Monitoring the Remediation of NAPL Contamination in the Subsurface”. Oregon State University. Department of Civil, Construction, and Environmental Engineering. Corvallis. 2006.

[3] ANP. Anuário estatístico brasileiro do petróleo, gás natural e biocombustíveis 2017. Agência Nacional do Petróleo, Gás Natural e Biocombustíveis. Rio de Janeiro. 2017.

[4] FEAM. Fundação Estadual do Meio Ambiente. "Inventário de Áreas Contaminadas de Minas Gerais 2018”. Belo Horizonte. Brasil. 2018

[5] HÜSERS, N. et al. "Innovative site investigation tool for NAPL contaminated areas in Brazil. Águas Subterrâneas”. II Congresso Internacional de Meio Ambiente Subterrâneo. 2011.

[6] SCHUBERT, M. et al. "Using the soil gas radon as an indicator for ground contamination by non-aqueous phase-liquids”. Journal of Soils and Sediments, Vol. 1, n. 4, p. 217-222. 2001.

[7] CANTO, E. L. “O que é coeficiente de partição?”, Informe-se sobre a química. Teacher Edition, n. 55. 2016. 
[8] SCHUBERT, M. "Using radon as environmental tracer for the assessment of subsurface NonAqueous Phase Liquid (NAPL) contamination-A review”. The European Physical Journal Special Topics, Vol. 224, n. 4, p. 717-730, 2015.

[9] BARTON, Allan FM. "Solubility parameters", Chemical Reviews, Vol. 75, n. 6, p. 731-753. Wellington, New Zealand, 1975.

[10] ATLAS BRASIL. “Calafate/Nova Suíça/Jardim América, Belo Horizonte, MG. RM - Belo Horizonte". Disponível em http://www.atlasbrasil.org.br. Acesso em 02 de janeiro de 2018.

[11] GEOINFO - Infraestrutura de dados espaciais da Embrapa. "Mapa de solos do Estado de Minas Gerais". Embrapa. Dezembro, 2004. Disponível em: http://geoinfo.cnps.embrapa.br/layers/geonode\%3Alev_mg_estado_solos_lat_long_wgs84_vt. Acesso em 30 de janeiro de 2020.

[12] AMARAL, F. C. S. et. al. Boletim de Pesquisa e Desenvolvimento 63: Mapeamento de solos e aptidão agrícola das terras do estado de Minas Gerais. Rio de Janeiro: Embrapa solos, 2004 ISSN: 1678-0892, p. 60. 2004.

[13] LARA, Evelise Gomes. "Radônio nos gases do solo: distribuições e correlações com litologias e pedologias da RMBH-Região Metropolitana de Belo Horizonte”. Dissertação de mestrado. Departamento de Engenharia Nuclear - Universidade Federal de Minas Gerais - UFMG. 2013.

[14] MACHADO, M. F; SILVA, S. F. “Geodiversidade do estado de Minas Gerais”. Brasil: CPRM, 2010. Disponível em: http://www.cprm.gov.br/publique/GestaoTerritorial/Geodiversidade/Mapas-de-Geodiversidade-Estaduais-1339.html. Acesso em 02 de janeiro de 2020.

[15] U.S. GEOLOGICAL SURVEY. The Geology of Radon. Disponível em: http://energy.cr.usgs.gov/radon/georadon/3.html. 1995.

[16] LARA, E. G. et al. "Distribution of soil gas radon concentration in the metropolitan region of Belo Horizonte, Minas Gerais, Brazil and correlations with lithologies and pedologies". International Nuclear Atlantic Conference - INAC. Brasil. 2011. 
[17] ARTHUR, A. C. et al. "Metodologia para a quantificação da exalação do gás radônio em rochas ornamentais”. Geociências. São Paulo. v. 32, n. 1, p. 166-180. 2013.

[18] SCHUBERT, M; SCHULZ, H. "Diurnal radon variation in the upper soil layers and at the soilair interface related to meteorological parameters". Health Physics. V. 83, p. 91-96. July, 2002.

[19] SCHUBERT, M. et al. "Determination of radon partition coefficients between water and organic liquids and their utilization for the assessment of subsurface NAPL contamination". Science of the total environment, Vol. 376, n. 1, p. 306-316 - 2007.

[20] IBP. Instituto Brasileiro de Petróleo, Gás e Biocombustível. "Média de produção de petróleo dos poços onshore", https://www.ibp. org.br/observatorio-do-setor/. (2019). 